\title{
NK and K cell activity of human blood: differences according to sex, age, and disease
}

\author{
JENNIFER PENSCHOW AND IAN R. MACKAY \\ From the Clinical Research Unit of the Walter and Eliza Hall Institute of Medical Research and the Royal \\ Melbourne Hospital, Victoria, Australia
}

SUMmARY We report a study on the activity of NK cells ('natural' killer cells) and K cells (antibody-dependent killer cells) in human peripheral blood in health and disease. The 'targets' used were cells of the Chang cell-line, sensitised with rabbit anti-Chang cell antibody for $\mathrm{K}$ cell activity, and killing was assessed by release of radiochromium at effector: target ratios of 50:1 and 100:1. The positive findings were that NK cell activity, but not $\mathrm{K}$ cell activity, was greater in males and in youth, that NK cell activity was reduced in systemic lupus erythematosus, that neither NK nor K cell activity was altered in rheumatoid arthritis, and that $\mathrm{K}$ cell activity was reduced in chronic active hepatitis.

Immunopathic diseases may be associated with alterations in numbers and function of various of the subpopulation of mononuclear cells of the blood. The major subpopulation, that of $\mathrm{T}$ cells, has been particularly studied and, T-lympopenia and deficient T cell function characterise systemic lupus erythematosus (SLE) and related diseases (Toh et al., 1973). Another subpopulation which comprises those cells which mediate antibody-dependent cytotoxicity (Perlmann and Holm, 1969; MacLennan et al., 1969), were called K cells (Anonymous, 1973). A further cellular effector function, that of natural cytotoxicity, has been identified by the demonstration firstly in mice (Greenberg and Playfair, 1974) and subsequently in man (Rosenberg et al., 1974; Jondal and Pross, 1975), that cells from lymphoid organs of normal donors are cytotoxic in vitro to non-antibody-coated tumour cell targets, and the cells involved have been called 'natural' killer (NK) cells (Kiessling et al., 1975).

The exact nature of cells mediating NK and K cell cytotoxicity has yet to be established, and it is still not established whether NK and K cells are the same or different cell types. Perlmann et al. (1975) have discussed the type of effector cell which mediates killing and differing target cells which can be used.

Accepted for publication 12 February 1979

Correspondence to Dr Ian R. Mackay, Clinical Research Unit, Walter and Eliza Hall Institute of Medical Research, Post Office, Royal Melbourne Hospital, Victoria 3050, Australia.
Cooper et al. (1977) described the NK and K cells as non-adherent, non-thymus-derived $\mathrm{Fc}$ receptor bearing lymphocytes which lack surface immunoglobulin. West et al. (1977), using as targets a myeloid cell line, concluded that the human NK cell was a cell with Fc receptors, no complement receptors and possibly low-affinity receptors for sheep erythrocytes, and co-identity between NK and $T$ cells was suggested.

The present study was designed to assess $\mathrm{K}$ cell and NK cell activity in peripheral blood of healthy persons to determine whether activity differed according to sex and age, and to establish whether various immunopathic diseases, SLE, rheumatoid arthritis (RA) and chronic active hepatitis (CAH) were associated with altered $\mathrm{K}$ or NK activity.

\section{Patients and methods}

\section{GROUPS OF SUBJECTS STUDIED}

Healthy persons were selected on the basis of pairing with patients in the disease groups under study (see below). The healthy persons (medical and laboratory staff) comprised 26 females whose mean age \pm standard deviation was $30 \pm 4$ years and 17 males whose mean age was $35 \pm 4$; of the 26 females, 17 were aged between $20-40$ and 9 between 40-60.

Diagnostic criteria for the diseases studied were as described by Morris et al. (1977). In brief, the 20 cases of SLE fulfilled the preliminary criteria of the American Rheumatism Association (ARA), including 
at least 1 visceral site involved and at least 1 positive response to the LE cell test; the 20 cases of RA had classical, definite, or probable disease according to the ARA criteria; and the 20 cases of CAH were those of the autoimmune or 'lupoid' type. Each disease group was paired with a healthy control group, matched for sex and, as closely as possible, for age. For the 3 groups SLE, RA, and CAH the female: male ratio was respectively $18: 2$, $12: 8$, and $14: 6$, and the mean ages in years (controls in parentheses) were respectively $35 \pm 13$ $(35 \pm 13), 54 \pm 10(49 \pm 18)$, and $37 \pm 17(38 \pm$ 19). Most of the patients studied were, or had been, on treatments aimed at suppressing disease activity; the number of recently seen untreated patients was not sufficient for meaningful analysis. The drugs used were, for SLE and CAH, prednisolone sometimes combined with azathioprine, and, for RA, combinations of anti-inflammatory drugs.

\section{TARGET CELLS}

Cells from the Chang cell-line (Commonwealth Serum Laboratories, Melbourne) were maintained as monolayer cultures in Dulbecco's modified Eagle's medium (Grand Island Biological Co., Grand Island, New York), containing $100 \mathrm{IU} / \mathrm{ml}$ penicillin and streptomycin and supplemented with heat-inactivated $10 \%$ fetal calf serum (FCS) (Flow batch B 60129).

\section{PREPARATION OF ANTISER UM}

Three outbred albino rabbits were immunised by multiple intradermal injections of 10 million washed Chang cells emulsified in Freund's complete adjuvant (FCA), as described by MacLennan et al. (1969), followed by a booster injection of 10 million Chang cells intravenously at 21 days. The rabbits were bled $(35 \mathrm{ml})$ after 18 days, and serum was separated and loaded on to a column of protein-A Sepharose (Pharmacia, Uppsala, Sweden). The immunoglobulin $\mathrm{G}$ (IgG) was eluted with $0 \cdot 15$ $M$ sodium chloride containing $0.58 \% \mathrm{v} / \mathrm{v}$ glacial acetic acid, pH 4.5, and the eluate was dialysed overnight at $4^{\circ} \mathrm{C}$ against phosphate buffered saline (PBS), pH 7·2. The dialysed eluate was centrifuged at $12000 \mathrm{~g}$, and the protein concentration of the supernatant was determined. Various dilutions were assessed for anti-Chang cell activity. The preparation was diluted in PBS, pH $7 \cdot 2$, to the lowest concentration producing optimal cytotoxocity and was stored at $-20^{\circ} \mathrm{C}$.

PREPARATION OF $\mathrm{F}^{\left(\mathrm{ab}^{\prime 1}\right)^{2}}$ FRAGMENTS

IgG, prepared as described above, was equilibrated with $0.2 \mathrm{M}$ acetate buffer at $\mathrm{pH} 4.5$ by dialysis for 5 hours at $4^{\circ} \mathrm{C}$. Pepsin was added at $2.5 \times 10^{-3}$ $\mu \mathrm{g} / \mathrm{ml}$ until the level of protein reached $10^{-2}$ that of IgG. The mixture was left overnight at $37^{\circ} \mathrm{C}$ and then dialysed for 48 hours at $4^{\circ} \mathrm{C}$ against PBS, $\mathrm{pH} 7 \cdot 2$. The digest was passed through a protein-A Sepharose column to remove undigested antibody; the $F\left(a b^{\prime}\right)_{2}$ fragments were dialysed for 18 hours at $4^{\circ} \mathrm{C}$ against PBS, pH $7 \cdot 2$, and centrifuged at $5000 \mathrm{~g}$ for 15 minutes. The protein concentration of the supernatant was measured and the preparation diluted to the same protein concentration as the rabbit anti-Chang IgG with $\mathrm{PBS}, \mathrm{pH} 7 \cdot 2$, and stored at $-20^{\circ} \mathrm{C}$.

\section{EFFECTOR CELLS}

Effector cells were obtained from heparinised human peripheral blood after centrifugation through Isopaque-Ficoll (Böyum, 1968). The resulting cell population was washed twice and resuspended in Eagle's minimum essential medium containing $10 \%$ FCS and $100 \mathrm{IU} / \mathrm{ml}$ penicillin and streptomycin.

\section{TARGET CELLS}

Subconfluent cultures of Chang cells were held overnight with $3 \mu \mathrm{Ci} / \mathrm{ml}$ of ${ }^{51} \mathrm{Cr}$-labelled sodium chromate, specific activity $100-400 \mu \mathrm{Ci} / \mu \mathrm{g}$ (CIS, France); cell suspensions were prepared by exposing monolayers to $0 \cdot 1 \%$ trypsin in PBS, $\mathrm{pH} 7 \cdot 2$, for 10 minutes at $37^{\circ} \mathrm{C}$. After 3 washes in balanced salt solution with $10 \%$ FCS the cells were adjusted to a final concentration of $2.5 \times 10^{4}$ viable cells per $\mathrm{ml}$.

\section{CHROMIUM RELEASE ASSAYS}

Assays were performed under sterile conditions in flat-bottomed microtitre trays (Linbro Scientific) in a total volume of $200 \mu \mathrm{l}$ at effector: target (E:T) ratios of 50:1 and 100:1. For each E:T ratio used there were 12 wells, each containing $100 \mu l$ target cells, $50 \mu$ of either F $\left(\mathrm{ab}^{\prime}\right)_{2}$ in PBS (4 wells), rabbit anti-Chang IgG (4 wells), or PBS (4 wells) as a control for toxic substances in the $\mathrm{F}\left(\mathrm{ab}^{\prime}\right)_{2}$ preparation which might cause lysis. Spontaneous lysis in the absence of effector cells and of antibody was ascertained, and maximum lysis was effected by a solution of $1.5 \%$ Nonidet P40 detergent (Triton $\mathrm{X}-100$ ). The wells were held for 18 hours at $37^{\circ} \mathrm{C}$ in $7.5 \% \mathrm{CO}_{2}$ in air, and $100 \mu \mathrm{l}$ of supernatant was aspirated from each well and counted in a Packard automatic gamma spectrometer.

\section{COUNTS OF LEUCOCYTES AND E ROSETTE-} FORMING CELLS

Differential leucocyte counts were made according to Dacie and Lewis (1975), and counts of E-rosetteforming cells (E-RFC) as described by Whittingham et al. (1977). 
EXPRESSION OF RESULTS AND STATISTICS NK cell activity ( $\%$ cytotoxicity) was expressed as:

$\underline{\left({ }^{51} \mathrm{Cr} \text { release in presence of } \mathrm{F}\left(\mathrm{ab}^{\prime}\right)_{2}-\text { spontaneous release }\right) \times 100}$ maximum release - spontaneous release

and $K$ cell activity (antibody-dependent cellmediated cytotoxicity) as:

${ }^{(51} \mathrm{Cr}$ release in $\mathrm{IgG}-{ }^{51} \mathrm{Cr}$ release in presence of $\left.\mathrm{F}\left(\mathrm{ab}^{\prime}\right)_{2}\right) \times 100$ maximum release - spontaneous release

Spontaneous release ranged between $23 \%$ and $30 \%$.

Data for the healthy control subjects are presented for males and females, and according to the age ranges 20-39 and 40-59, and for each of the disease groups compared with their matched controls. Results are expressed for E:T ratios of 50:1 and 100:1, and for NK and K cell activity. Differences between means were compared for significance by the Mann-Whitney rank test; one-tailed significance levels are cited.

\section{Results}

\section{NK-CELL-MEDIATED CYTOTOXICITY}

The data for all groups are shown in Fig. 1. Among the healthy subjects levels of NK-cell-mediated cytotoxicity were considerably greater in males than in females, and in younger than in older females. The NK cell cytotoxicity of the females was $56 \%$ and $65 \%$ of that of the males at the two E:T ratios

NK CELL CYTOTOXICITY

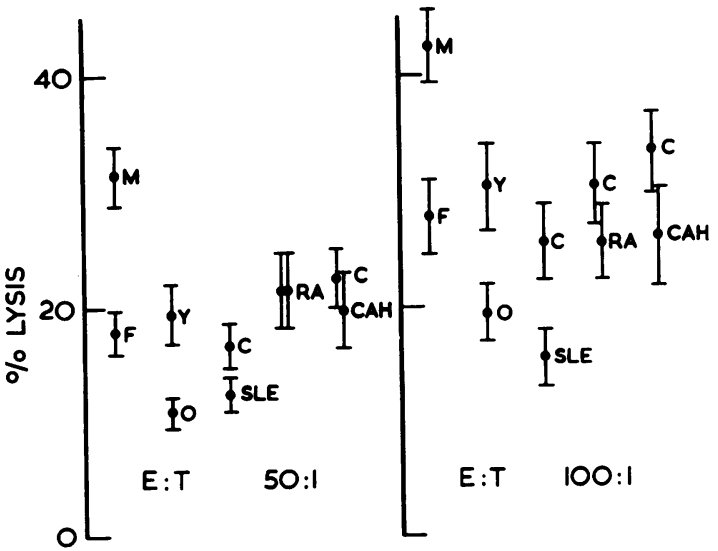

Fig. 1 Comparison of NK cell cytotoxicity according to sex, age (females), and disease, at effector-to-target ratios of 50:1 and 100:1. For the diseases considered patients were age and sex matched with healthy controls. NK cell cytotoxicity was significantly greater in males and in younger than older females, and significantly less in systemic lupus erythematosus (SLE) at E:T 100:1 of 50:1 and 100:1, and these differences were significant $(P<0.001 ; P<0.005)$. The effect of age was assessed only in females, the number of males being too few for analysis. At E:T ratios of 50:1 and 100:1 the NK cell cytotoxicity of the older females was $56 \%$ and $64 \%$ of that of the younger females $(\mathrm{P}<0.05$ for $\mathrm{E}: \mathrm{T}$ of 100:1).

For patients with SLE, NK cell cytotoxicity was significantly lower than for controls at the E:T ratio of 100:1 $(P<0.005)$. Depressed NK cell cytotoxicity in SLE could not be correlated with the clinically assessed severity of disease nor with treatment regimens (data not shown). For patients with RA and CAH, NK cell cytotoxicity was not significantly different from that of the controls. Correlation coefficients were calculated for NK cell cytotoxicity and numbers of circulating lymphocytes, monocytes, and E-RFC in the blood, but no statistically significant relationships were demonstrable.

K-CELL-MEDIATED (ANTIBODY

DEPENDENT) CYTOTOXICITY

The data for all groups are shown in Fig. 2. Among healthy subjects $\mathrm{K}$ cell cytotoxicity, in contrast to NK cell cytotoxicity, was similar to females and males, and older females showed a slight and nono significantly greater degree of $\mathbf{K}$ cell cytotoxicity than did younger females. For patients with SLE and RA, $\mathrm{K}$ cell cytotoxicity was similar to that of the controls, but patients with $\mathrm{CAH}$ showed significantly less $\mathrm{K}$ cell activity than did controls at $\mathrm{E}: \mathrm{T}$ ratios of 50:1 and 100:1 (P<0.05). The degree of $K$ cell cytotoxicity had no relationship to the number of circulating lymphocytes, monocytes, or E-RFC when correlation coefficient analyses were applied.

\section{K CELL CYTOTOXICITY}

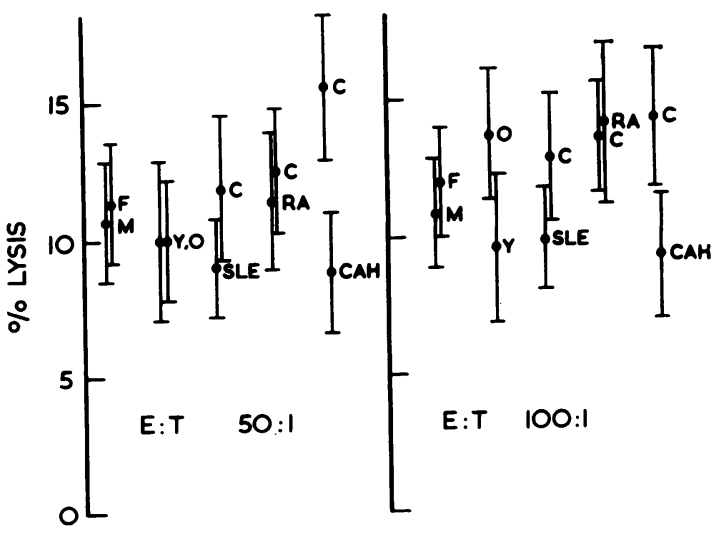

Fig. 2 Comparison of $K$ cell cytotoxicity according to sex, age (females), and disease, at effector-to-target ratios of 50:1 and 100:1. There was a significantly lower $K$ cell cytotoxicity in chronic active hepatitis $(C A H)$. 


\section{Discussion}

This study describes the measurement of nonspecific cell-mediated cytotoxicity in man by means of peripheral blood lymphocytes as effector cells and Chang cells as targets, in effector-to-target ratios of 50:1 and 100:1. The method allowed for separate assessment of natural killer (NK) cell cytotoxicity and antibody-dependent (K) cell cytotoxicity. Among healthy persons NK cell cytotoxicity in males was significantly greater than that in comparably aged females. and activity in females was lower in the older than the younger, but $\mathrm{K}$ cell cytotoxicity did not differ according to sex or age. Among the disease groups studied the level of NK cell cytotoxicity was greatly reduced in patients with SLE, and the level of $\mathrm{K}$ cell cytotoxicity was moderately reduced in patients with CAH.

Laboratory procedures for assessment of $\mathrm{NK}$ and $\mathrm{K}$ cell activity in man are far from standardised, and methodological variables and differences which could invalidate comparisons of published results on nonspecific cytotoxicity of human blood cells include the target-cell and E:T ratios used, failure to dissociate effects attributable to $\mathrm{NK}$ and $\mathrm{K}$ cell cytotoxicity and influence of sex and age. Given these variables, we may note that the higher level of NK cell cytotoxicity in our study in males, and in younger as opposed to older subjects, corresponds with reported findings in mice and guineapigs (Roder and Kiessling, 1978; Altman and Rapp, 1978) and in man (Santoli et al., 1978), using tumour cells as targets, although a consensus on sex and age effects in man is not yet available (Herberman and Holden, 1978). Petranyi et al. (1974) and Santoli et al. (1976) suggested that in man genetic factors could regulate NK cell and $\mathrm{K}$ cell cytotoxicity, because the hyperactivity of males was associated with HLA B12. Correlations between HLA and degrees of cytotoxicity were not sought in the present study.

In SLE there have been several studies on non-T cell cytotoxicity and low levels of activity have been reported (Schneider et al., 1975), but whether this could be attributed to decreased NK or $\mathrm{K}$ cell activity is uncertain. Horwitz and Juul-Nielsen (1977) described the 'L lymphocyte' as a possible mediator of NK cell activity and found in patients with SLE that this cell type was reduced in number to $50 \%$ of normal. This would be consistent with the low NK cell activity of our patients with SLE. A reduction in number and activity of $L$ (or NK) cells in SLE was attributed to an effect of coldreactive lymphocytotoxic antibodies (Horwitz and Juul-Nielsen, 1977).

In rheumatoid arthritis there are differing reports on the degree of non-T cell cytotoxicity. Isturiz et al. (1976) and McGill and Twinn (1977), using sheep erythrocytes as targets, found antibodydependent cellular cytotoxicity to be reduced, and in the latter study the degree of reduction correlated with activity of the disease. On the other hand DiazJouanen et al. (1976), using chicken erythrocytes as targets, and Panayi and Corrigall (1977) using Chang cells as targets, calculated from assays of $\mathrm{K}$ cell activity that the number and functional capacity of $\mathbf{K}$ cells in rheumatoid arthritis was similar to that of controls.

Chronic active hepatitis has not been widely studied from the standpoint of the integrity of nonspecific cellular cytotoxicity, though cellular cytotoxicity has been implicated as the cause of liver cell destruction in this disease (Cochrane et al., 1978). Vierling et al. (1977), using tumour cells as targets, reported normal NK and $\mathrm{K}$ cell activity in a small group of patients with chronic active and chronic persisting hepatitis, whereas Cochrane et al. (1978), using visual assessment of cytotoxicity for rabbit liver cells as targets, found above-normal levels in untreated $\mathrm{CAH}$, with a decrease towards their normal range during remission. In the present study it was found that $\mathrm{K}$ cell (although not NK cell) activity was lower than for controls. Possibly treatment with azathioprine, which had been taken by most of our patients as an immunosuppressive drug, could account for this (Eckhardt et al., 1977). Kakumu et al. (1978) reported that non-T-cellmediated cytotoxicity against Chang cell targets was increased in $\mathrm{CAH}$, and, since the targets were not coated with antibody added to the system, NK activity was apparently responsible. The less likely possibility was that small amounts of antibody reactive with Chang cells could have been released by some B cells in the culture. In view of the several studies in CAH (Kakumu et al., 1978; Cochrane et al., 1978) claiming that peripheral blood mononuclear cells not identifiable as $T$ cells have augmented cytotoxicity for liver cells from various sources as targets, the question of $\mathrm{K}$ and NK activity in CAH seems to need a further experimental assessment.

We are grateful to Dr Jon Buckley for statistical analyses and to Miss Jennifer Bluett for expert technical assistance. The authors were supported by grants from the Victorian Lions' Cancer Research Fund (JP) and the National Health and Medical Research Council of Australia (IRM).

\section{References}

Altman, A., and Rapp, H. J. (1978). Natural cell-mediated cytotoxicity in guinea pigs: properties and specificity of natural killer cells. Journal of Immunology, 121, 2244-2252. 
Anonymous (1973). Advances in immunopathology. Nature New Biology, 243, 225-226.

Böyum, A. (1968). Isolation of mononuclear cells and granulocytes from human blood. Isolation of mononuclear cells by one centrifugation, and of granulocytes by combining centrifugation and sedimentation at $1 \mathrm{~g}$. Scandinavian Journal of Clinical and Laboratory Investigation, 21, Supplement 97, 77-89.

Cochrane, A. M. G., Moussouros, A., Smith, A., Portmann, B., Eddleston, A. L. W. F., and Williams, R. (1978). Lymphocyte cytotoxicity in chronic active hepatitis: effect of therapy and correlations with clinical and histological changes. Gut, 19, 308-314.

Cooper, S. M., Hirsen, D. J., and Friou, G. J. (1977). Spontaneous cell-mediated cytotoxicity against Chang cells by non-adherent, non-thymus-derived, Fc receptorbearing lymphocytes. Cellular Immunology, 32, 135-145.

Dacie, J. V., and Lewis, S. M. (1975). Practical Haematology. Churchill-Livingstone: Edinburgh.

Diaz-Jouanen, E., Bankhurst, A. D., and Williams, R. C., Jr. (1976). Antibody mediated lymphocytotoxicity in rheumatoid arthritis and systemic lupus erythematosus. Arthritis and Rheumatism, 19, 133-141.

Eckhardt, R., Kloos, P., Dierich, M. P., and Meyer zum Buschenfelde, K. H. (1977). K-lymphocytes (killer cells) in Crohn's disease and acute virus B. hepatitis. Gut, 18, 1010-1016.

Greenberg, A. H., and Playfair, J. H. L. (1974). Spontaneously arising cytotoxicity to the P-815-Y mastocytoma in NZB mice. Clinical and Experimental Immunology, 16, 99-100.

Herberman, R. B., and Holden, H. T. (1978). Natural cellmediated immunity. Advances in Cancer Research, 27, 305-377.

Horwitz, D. A., and Juul-Nielsen, K. (1977). Human blood L-lymphocytes in patients with active systemic lupus erythematosus, rheumatoid arthritis and scleroderma: a comparison with $\mathrm{T}$ and $\mathrm{B}$ cells. Clinical and Experimental Immunology, 30, 370-378.

Isturiz, M. A., De Bracco, M. M. E., Pizzi, A. M., and Manni, J. A. (1976). Antibody-dependent cell-mediated cytotoxicity in rheumatoid arthritis. Arthritis and Rheumatism, 19, 725-730.

Jondal, M., and Pross, H. (1975). Surface markers on human T and B lymphocytes. IV. Cytotoxicity against cell lines as a functional marker for lymphocyte subpopulations. International Journal of Cancer, 15, 596-605.

Kakumu, S., Hara, T., Goji, H., and Sakamoto, N. (1978). Lymphocyte cytotoxicity against Chang liver cells in chronic active hepatitis. Cellular Immunology, 36, 46-53.

Kiessling, R., Klein, E., and Wigzell, H. (1975). 'Natural' killer cells in the mouse. I. Cytotoxic cells with specificity for mouse Moloney leukemia cells. Specificity and distribution according to genotypes. European Journal of Immunology, 5, 112-117.

MacLennan, I. C. M., Loewi, G., and Howard, A. (1969). A human serum immunoglobulin with specificity for certain homologous target cells, which induces target cell damage by normal human lymphocytes. Inmunology, 17, 897-910.

McGill, P. E., and Twinn, I. (1977). Antibody-mediated cytotoxicity in rheumatoid arthritis. Annals of the Rheumatic Diseases, 36, 268-270.
Morris, P. J., Vaughan, H., Tait, B. D., and Mackay, I. R. (1977). Histocompatibility antigens (HLA): Associations with immunopathic diseases and the responses to microbial antigens. Australian and New Zealand Journal of Medicine, 7, 616-624.

Panayi, G. S., and Corrigall, V. (1977). Functional assay of cytotoxic lymphocytes in normal and rheumatoid subjects. Annals of the Rheumatic Diseases, 36, 257-260.

Perlmann, P., and Holm, G. (1969). Cytotoxic effects of lymphoid cells in vitro. Advances in Immunology, 11, 117-193.

Perlmann, P., Perlmann, H., Larsson, A., and Wahtin, B. (1975). Antibody-dependent cytotoxic effector lymphocytes (K cells) in human blood. Journal of the Reticuloendothelial Society, 17, 241-250.

Petranyi, G. Gy., Benczur, M., Onody, C. E., and Hollan, S. R. (1974). HL-A 3,7 and lymphocyte cytotoxic activity. Lancet, 1, 736.

Roder, J. C., and Kiessling, R. (1978). Target-effector interaction in the natural killer cell system. Scandinavian Journal of Immunology, 8, 135-144.

Rosenberg, E. B., McCoy, J. L., Green, S. A., Donnelly, F. C., Siwarski, D. F., Levine, P. H., and Herberman, R. B. (1974). Destruction of human lymphoid tissueculture cell lines by human peripheral blood lymphocytes in ${ }^{51} \mathrm{Cr}$ release cellular cytotoxicity assays. Journal of the National Cancer Institute, 52, 345-352.

Santoli, D., Trinchieri, G., Zmijewski, C. M., and Koprowski, H. (1976). HLA-related control of spontaneous and antibody-dependent cell-mediated cytotoxic activity in humans. Journal of Immunology, 117, 765-770.

Santoli, D., Trinchieri, G., Moretta, L., Zmijewski, C. M., and Koproski, H. (1978). Spontaneous cell-mediatedo cytotoxicity in humans. Distribution and characterization. of the effector cell. Clinical and Experimental Immunology, 33, 309-318.

Schneider, J., Chin, W., Friou, G. J., Cooper, S. M., Harding, B., Hill, R. L., and Quismorio, F. P. (1975). Reduced antibody-dependent cell-mediated cytotoxicity in systemic lupus erythematosus. Clinical and Experimental Immuno$\log y, 20,187-193$.

Toh, B. H., Roberts-Thomson, I. C., Mathews, J. D., Whittingham, S., and Mackay, I. R. (1973). Depression of cell-mediated immunity in old age and the immunopathic diseases, lupus erythematosus, chronic hepatitis and rheumatoid arthritis. Clinical and Experimental Immunology, 14, 193-202.

Vierling, J. M., Nelson, D. L., Stober, W., Bundy, B. M., and Jones, E. A. (1977). In vitro cell-mediated cytotoxicity in primary biliary cirrhosis and chronic hepatitis. Dysfunction of spontaneous cell-mediated cytotoxicity in primary biliary cirrhosis. Journal of Clinical Investigation, 60, 1116-1128.

West, W. H., Cannon, G. B., Kay, H. D., Bonnard, G. D., and Herberman, R. B. (1977). Natural cytotoxic reactivity of human lymphocytes against a myeloid cell line: characterization of effector cells. Journal of Immunology, 118, 355-361.

Whittingham, S., Pitt, D. B., Sharma, D. L. B., and Mackay, I. R. (1977). Stress deficiency of the T-lymphocyte system exemplified by Down's syndrome. Lancet, 1, 163-166. 